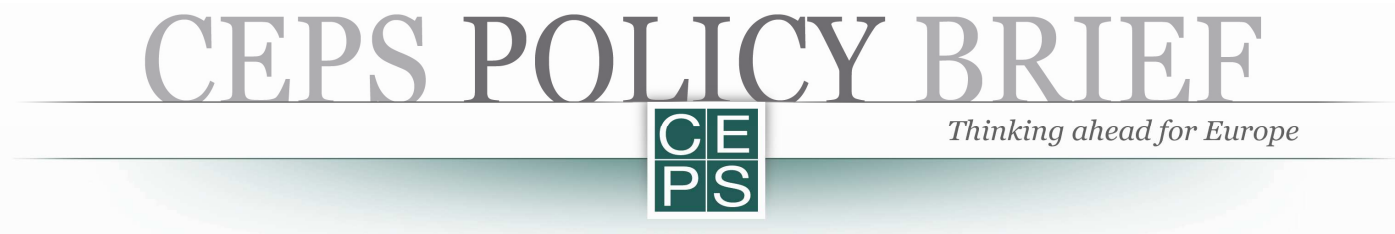

\title{
Speculative Attacks within or outside a Monetary Union: Default versus Inflation (what to do today)
}

\author{
Daniel Gros
}

\section{No. 257, November 2011}

\section{Introduction}

Is a high level of public debt inherently more dangerous within a monetary union? During the 1990s it was often argued that only by entering the EMU could Italy (or Spain) protect itself from the high interest rates it had to pay on its large public debt. The argument was that by joining the single currency, Italy could convince financial markets that it would not inflate away the value of its debt and hence benefit from lower risk premia.

Oddly enough, the opposite argument is often used today to explain Italy's current high risk premium: Italy (and Spain) has to pay a high risk premium because it has lost the option to use the printing press, so the argument goes today. Moreover, it has been argued that the higher interest burden could go beyond the willingness of the population to pay taxes, thus pushing the country into default if interest rates stay too high.

This note first argues that a priori default and inflation should be two equivalent ways to reduce the burden of a high public debt and, similarly, two equivalent types of risk to which an investor who lends funds to a government is exposed (this is not of course a novel observation). This would suggest that, in principle, belonging to a monetary union does not lead systematically to higher risk premia.
The historical record shows that during the early 1990s Italy faced a much higher burden in terms of high interest rates and interest expenditure than today. Nevertheless the current position of Italy is perceived as even more dangerous than then.

The key question that remains at the analytical level is thus whether there are other mechanisms that make a formal default with a haircut different from debt monetisation, which reduces the purchasing power for investors by the same amount. This paper argues that there is indeed a difference because a formal sovereign default invariably leads to a banking crisis. Moreover, within a monetary union a sovereign is more exposed to liquidity problems than a country with an independent currency and any of its problems quickly spill over into the banking system, which cannot survive without a reliable source of liquidity given that banks are by nature highly leveraged institutions.

In terms of policy prescriptions, one conclusion is that less effort and financing should be devoted to trying to lower yields on peripheral government debt, but a lender of last resort is needed for both sovereigns and the banks. Another policy priority should be to stabilise the banking system in such a way that it can survive even if government debt yields increase.

Daniel Gros is Director of the Centre for European Policy Studies.

CEPS Policy Briefs present concise, policy-oriented analyses of topical issues in European affairs, with the aim of interjecting the views of CEPS researchers and associates into the policy-making process in a timely fashion. Unless otherwise indicated, the views expressed are attributable only to the author in a personal capacity and not to any institution with which he is associated.

Available for free downloading from the CEPS website (http:/ / www.ceps.eu) • (c) CEPS 2011 


\section{The analytical issue}

\section{Instability of high public debt within and outside a monetary union}

It is commonplace by now that a high level of public debt can lead to positive, vicious, feedback loops and even multiple equilibria in a monetary union. The argument is quite simple: even a rather high level of public debt would be sustainable if the government had to pay only a low interest rate, say, close to the compensation required on a riskless investment. However, the same level of debt might become unsustainable, forcing a country into default, if the borrowing cost is much higher. Hence many authors (most persuasively de Grauwe, 2011) have argued that there might be multiple equilibria: if the market thinks the government can pay, it will be able to pay because its borrowing cost will be low. However, if the market thinks the government cannot pay, in practice it will not be able to pay because the high risk premium requested will make the debt service so expensive that it will not be able to find the necessary resources. Doubts about the ability of a government to service its debt could thus become self-fulfilling. This line of reasoning has been used to justify central banks' interventions in the market, for example, the bond purchase programme of the ECB, the Securities Market Programme (SMP).

Many economists seem to forget that during the 1990s a similar argument was used to justify the creation of EMU with an independent central bank. The reasoning was quite simple:

A fixed exchange rate regime can experience a self-fulfilling crisis if a high risk premium leads to high domestic interest rates that depress domestic activity, and thus make it more likely that the government will actually abandon the system. Depending on the parameter configuration, two equilibria might exist. One is characterized by low interest rates and a low (possibly zero) probability that the exchange rate commitment will be abandoned; the other is characterized by high interest rates and a high probability that the exchange rate commitment will be abandoned. (Adrian \& Gros (1999) ${ }^{1}$

1 Note that this quote refers to the analysis of a country under a fixed exchange regime; however it applies also to the case of free-floating exchange rates.
Countries with a high level of debt thus seem to be presented with only bad choices: if they enter a monetary union, a speculative attack can force them to default. But if they keep their monetary autonomy, a speculative attack can force them into high inflation. Calvo (1988) confirms this: he considers both the case of a country with monetary autonomy and the case of a country without monetary autonomy. He finds that multiple equilibria can arise in both cases. He also finds that in both cases the high interest rate equilibrium is Pareto inferior.

This type of result is not surprising. From the point of view of investors, it should not really matter whether the government defaults on its obligations and imposes a haircut on investors or whether it is forced into high inflation, which then reduces the real value of the debt securities they hold, even without a formal default. An example easily proves this point. Assume for instance that within a monetary union the probability of a default of a member country is $1 / 5$ and that the haircut in case of default is $20 \%$. This would justify an interest rate premium (over the riskless rate) of 4 percentage points. If the country had kept its own currency, the risk of abandoning the hard currency policy might also be $1 / 5$ and the inflation rate, in case the hard currency option is abandoned, might be also $20 \%$. This would also require for a riskneutral investor an additional compensation (risk premium) of 4 percentage points. The risk (and thus its price) should be the same under both circumstances: i.e. being part of a monetary area or having one's own currency.

One could of course argue that, at least for a euro area member country, both the cost of defaulting on government debt and that of exiting the euro area would be much higher than the cost of merely exiting a fixed exchange rate regime (and permitting inflation to increase to double digit figures). However, the usual models of speculative attacks would then also imply that, given the much higher cost of defaulting, the credibility of the government not to default

The debt burden in both cases would be reduced through inflation; the difference is that under the fixed regime there is first a currency crisis and the exit from the hard peg regime. A number of other authors arrive at similar conclusions; see, for example, Obstfeld (1986 and 1995). 
should be much higher and consequently the likelihood of multiple equilibria much lower. This was indeed one argument widely used to show the advantages of a country giving up its currency.

A key aspect of the models of multiple equilibria is that with the bad equilibrium (with high interest rates) investors expect either inflation or a default, but the government is not necessarily forced to validate these expectations. This is indeed what happened during the turbulent period that preceded EMU.

\section{The case of Italy}

The case of Italy is instructive in this respect. Italy's debt-to-GDP ratio is today about $120 \%$, very close to the value of the early 1990s. At that time Italy was also in financial difficulties, with a much higher deficit and interest rates than today.

The key parameter for the government debt sustainability is the difference between the borrowing cost and the growth rate of GDP, which is often also called the 'snowball factor': If the interest rate is higher than the growth rate, the debt-to-GDP ratio will continue to grow and eventually explode unless the country continuously runs a primary surplus. In the case of Italy, since nominal GDP growth rates have not varied that much over time (2008-09 provides the only exception), the evolution of the snowball factor depends crucially on the 'risk premium', i.e. the difference between the riskfree rate and Italy's effective borrowing cost. Figure 1 shows the difference between the longterm interest rate on Italian government debt and the growth rate of nominal GDP (realised over the preceding twelve months). It is apparent, that the country was under extreme stress during the wave of speculative 'attacks' of the early 1990s. In 1993, when the authorities were still defending the peg within the European
Monetary System (EMS), the difference between the (nominal) interest rate and the growth rate of (nominal) GDP was over 10 percentage points. This did decline somewhat after the country left the EMS, but the snowball factor fluctuated around $8-9 \%$ during the following few years during which the exchange rate fluctuated widely and tensions in financial markets remained high.

At the time, the average maturity of public debt was rather low so that the higher nominal interest rates quickly resulted in higher government expenditure on interest, which remained above $11 \%$ of GDP over the period 1991-97.2

Compared to this period of flexible exchange rates, today's fiscal position of Italy does not seem so dire: the snowball factor remains, at around 4 percentage points, much below the level of over 8 percentage points of the early 1990s. The spread on German government securities (the benchmark risk-free rate) would have to double for the snowball effect to reach the same level of tension as 15 years ago. Moreover, interest on public debt now accounts for about $5 \%$ of GDP, again less than one-half the level during the 1990s and it would take several years before high interest rates would translate into materially higher interest expenditure for the government.

Figure 1 also suggests that the sharp fall in nominal GDP right after the Lehman collapse induced a short-lived spike in the snowball effect, which was apparently discounted by the financial markets because of its temporary nature.

\footnotetext{
2 Data from the European Commission services, Ameco database.
} 
Figure 1. Italy: snowball factor (interest rate minus growth of GDP) 1990-2011 and SEP ratings history

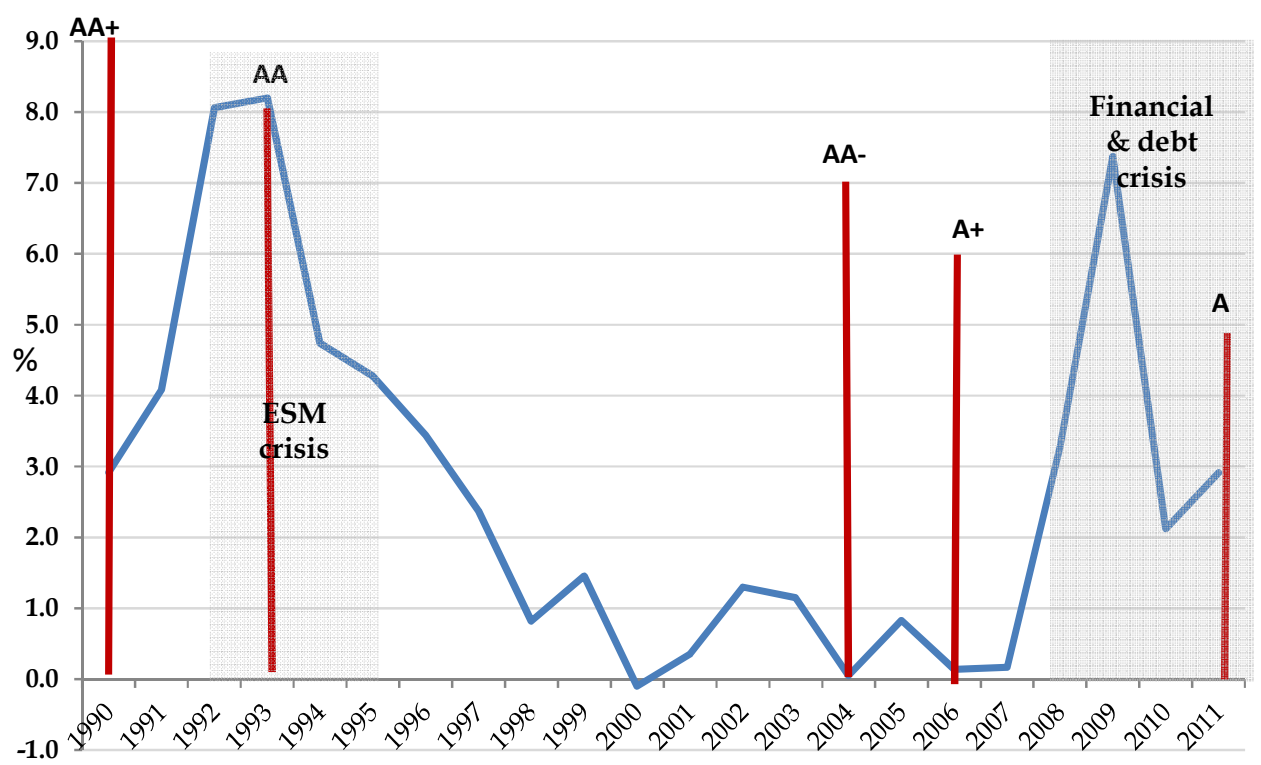

Note: The snowball factor is defined as the difference between the interest rate on 10-year government bonds and actual nominal growth rate.

Source: Own calculations based on data from the ECB, Commission Services (Ameco) and Standard \& Poor's.

What caused the rather rapid decline in the snowball factor (and the risk premium) after 1993? It is difficult, even ex-post, to disentangle the different factors that may have determined the adjustment. It is sometime argued that the prospect of joining the EMU played an important role.
But Figure 2 suggests that the very determined fiscal adjustment undertaken over this period must have been in the end decisive. Indeed, it is apparent that falls in the fiscal deficit (of general government) preceded at each step the large reductions in the snowball factor that materialised until the start of EMU.

Figure 2. Italy: Snowball factor and the government deficit (1993-2011)

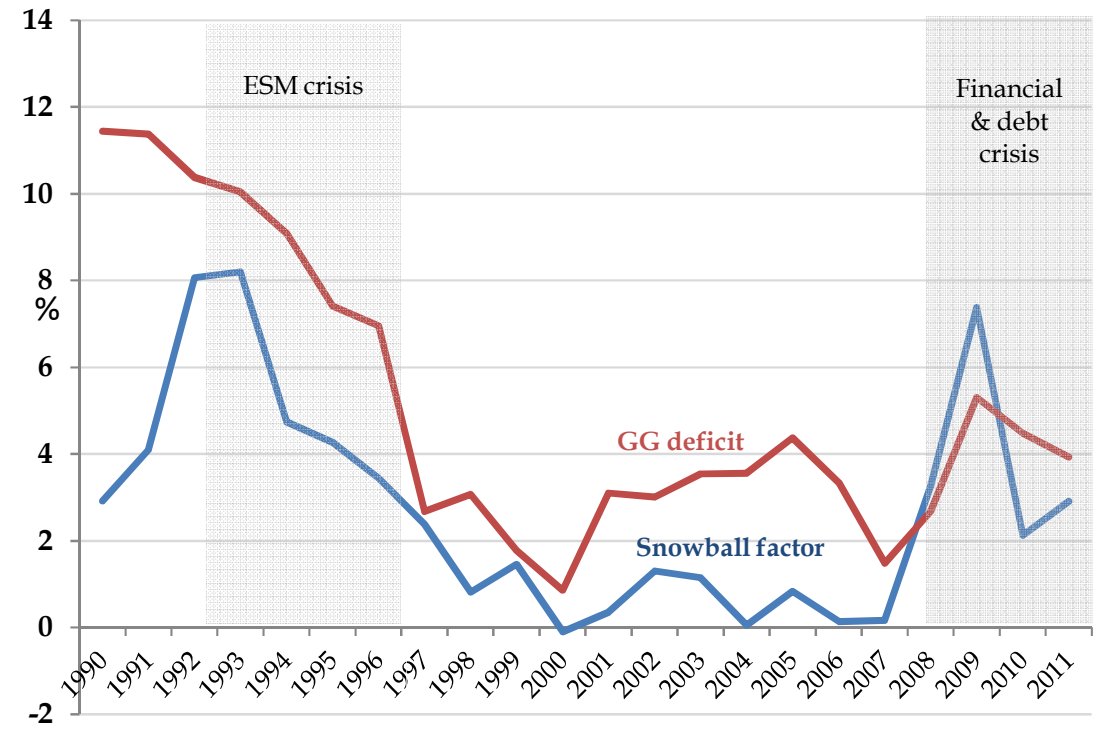

Source: Own calculations based on ECB and European Commission Services (Ameco) data. 
In the light of the current emphasis on growth, it is interesting to note that the sharp fiscal adjustment of the mid- to end 1990s did not seem to have depressed growth enough to prevent these reductions in the snowball factor, which already incorporates any negative effects of a fiscal adjustment on growth. ${ }^{3}$ This episode goes against the argument that a cut in expenditure (or an increase in taxes) would be self-defeating because it reduces demand and hence GDP. Moreover, if it were true, it would follow that tax cuts would actually lead to lower deficits because higher growth would more than offset the lower tax revenues. This proposition has been tested several times in the US, but supporting evidence was never found. ${ }^{4}$
Another indicator of the pressure on government finances during the 1990s is the amount spent on interest payments. Figure 3 shows interest payments on general government debt as a percentage of GDP. It is apparent that during that time interest payments were much more important than today. During the several years the Italian government had to spend over $10 \%$ of GDP on interest payments alone. Today it is still less than $5 \%$ of GDP and even if interest rates went to $8 \%$, the burden for the government would increase only slowly since the average maturity of Italian public debt is above $7 \%$ per year. With interest rates at $8 \%$ it would take probably until 2020 for interest payments to come close to $10 \%$ of GDP (under the assumption that the debt remains at $120 \%$ of GDP.

Figure 3. The interest burden in a longer perspective

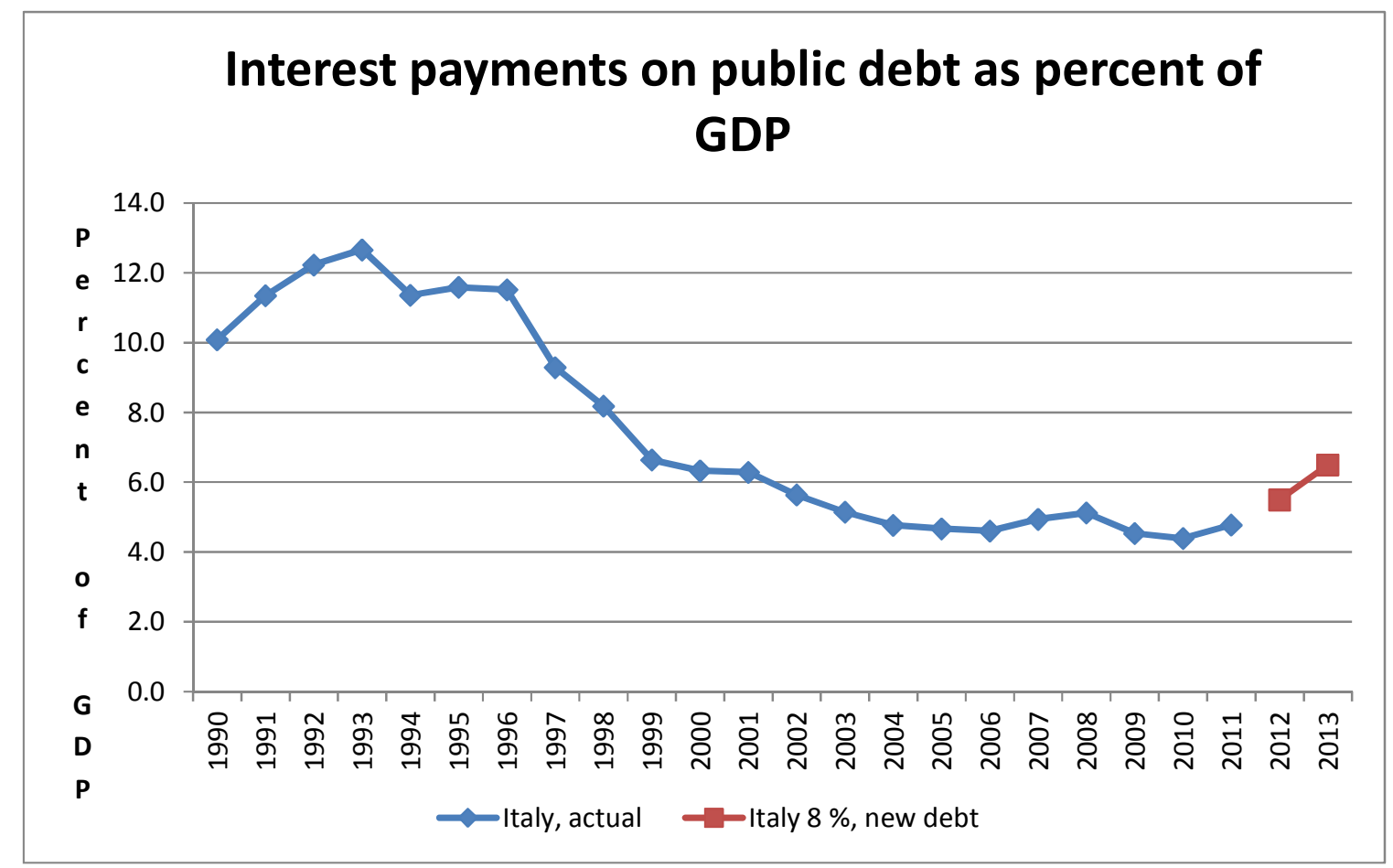

Source: European Commission Services (Ameco) data.

3 Moreover, as suggested by the literature on nonKeynesian effects which flourished in the late 1990s (among other see Giavazzi \& Pagano, 1996), fiscal adjustments (in the case of Italy combined with the prospect of joining the EMU) could have affected positively demand through confidence effects and offset the usual Keynesian effects.

4 See for instance the report by the Center of Budget and Policy Priorities on the expansionary policy of 2001-07 (CBPP, 2009). 
All in all, the experience of the 1990s suggests, contrary to the assertions of many commentators, that Italy's public finances cannot be said to be unsustainable at interest rates beyond $5-6 \%$ and a snowball factor around 4-5 percentage points.

How is the current situation different from the 1990s? First of all, the market turbulences during the summer of 2011 suggest that the risk premium alone does not seem to represent a comprehensive indicator of the degree of crisis of a country. Yields on Italian government bonds increased substantially over the summer of 2011, but remained low by the standards of the 1990s. Yet tensions on the financial markets were (and still are) extremely high with the flash point for financial markets being the banking system: the shares of Italian banks have plunged to multiyear lows and these banks are no longer able to refinance themselves on the interbank market.
Secondly, in order to make spreads in the 1990s and today fully comparable, one should eliminate the currency risk component from the former. For this purpose one should consider the behaviour of the risk premium on Italy's foreign currency debt. As shown in Figure 4, which displays the difference between the yield on a very long dated Italian government bond denominated in US dollars and US government securities, throughout the period when Italy experienced sustained speculative attacks on its currency, the risk premium on its foreign currency-denominated debt remained most of the time below 100 basis points. It is only in the summer of 2011 that the risk premium has risen to over 300 basis points (about the same magnitude as that on euro debt relative to Bunds).

Figure 4. Spreads on Italian sovereign bonds denominated in US dollars relative to US Treasury bonds

$\langle$ HELP〉 for explanation.

Govt HS

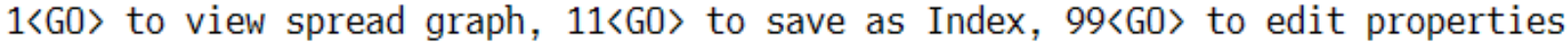
Sell $T 7^{1}{ }_{s}$ 02/15/23 Govt Buy ITALY $6{ }^{7}$ 09/23 Cor Edit Page 1/20 Yield Spread

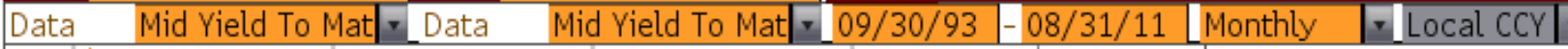

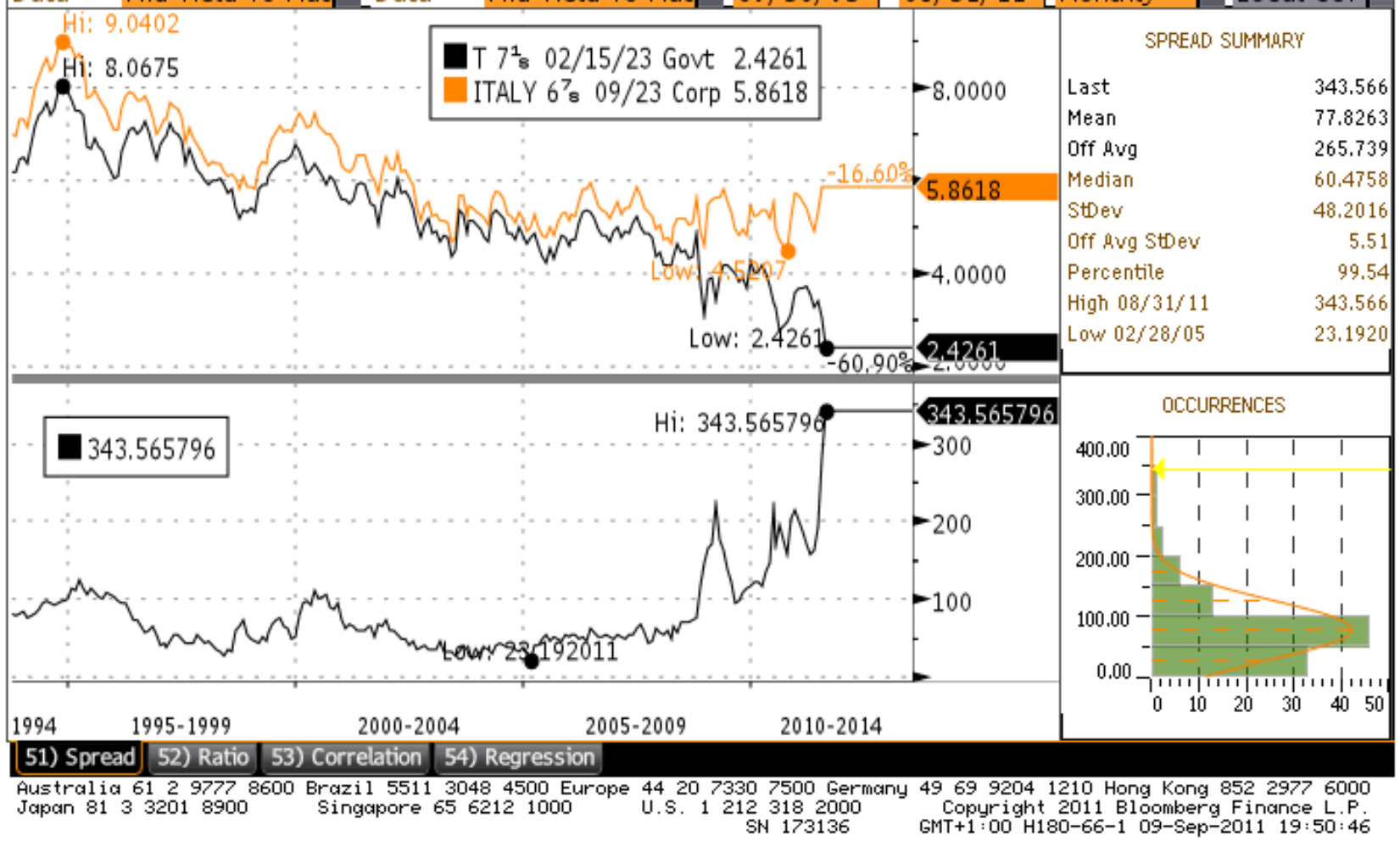

Source: Bloomberg. 
One way to interpret today's much higher risk premium would be of course to assert that markets at present have much less faith in the willingness of the Italian political system to do 'whatever it takes' to get public finances under control. ${ }^{5}$ Otherwise, the case of Italy would present a puzzle: on the one hand, the stress on government finances was much stronger during the 1990s than today, but, on the other hand, risk premia on foreign debt (and euro debt is effectively in a foreign currency) are much higher today.

That the willingness of the Italian political system to make the difficult choices needed to service the debt has been declining over the last decade is reflected in the long-term downward trend in the rating of the Italy's public debt. As shown earlier in Figure 1, the rating of Italy today is several notches below that of the mid1990s, although the debt level is about the same as a percentage of GDP. However, Italy's rating was lowered already twice beforehand (in 2004 and 2006), without provoking much reaction in the financial markets.

\section{Sovereigns like banks}

The considerations above reinforce the view that the fundamental problem for the euro area at present is not so much high interest rates on government debt and potentially multiple equilibria, but liquidity, both for the sovereign and the banking system.

For the sovereign, the problem can be summarised as a maturity mismatch issue: a government has long-term assets (flow of tax revenues) and liabilities of a much shorter duration. A country with a balanced budget would normally be considered solvent even if the debt-to-GDP ratio is $100 \%$, because with a balanced budget the debt-to-GDP ratio will decline towards zero as long as GDP grows in nominal terms. However, even if the average maturity of government debt is 8 years (rather conservative and almost the case for Italy), the same country has to refinance every year $12.5 \%$ of GDP - much above what even the strongest government could hope to finance out of a

5 This was one of the motivations for the recent downgrade of Italian debt; see Moody's report of 4 October 2011. surplus. This implies that any government could become immediately insolvent if investors refuse to roll over the debt coming due. This is exactly the same mechanism as in a bank run. If all depositors want their money back at the same time, the bank will not be able to liquidate immediately its loan portfolio (Diamond \& Dybwig, 1983).

The danger of a run on government debt does not exist outside a monetary union, under the assumption that the national central bank provides the liquidity needed to keep the sovereign solvent in the short run even in the event of a total investors' strike. The potential for bank runs and their widespread occurrence during the 1930s was the main reason why central banks became the lender of last resort for banks. Within the euro area, national governments, ${ }^{6}$ similarly to banks, need a liquidity back-up which can be provided only by the ECB. Any liquidity backstop mechanism whether for banks or for sovereigns - requires by definition a distinction between insolvency and illiquidity. For banks the final decision is usually taken by the fiscal authorities; Gros \& Mayer (2011) argue that one should also follow the same approach for euro area sovereigns.

The experience after the Lehman collapse has shown that the real economy is severely affected if liquidity in the interbank markets dries up. Since the summer of 2011, Europe has been going through a similar experience but for different reasons. Economists have difficulties capturing this transmission channel in their models and how it has changed with the advent of the euro. One concrete example of a specific mechanism at work is the ruling of a major London-based clearinghouse that states that the haircut on government bonds used in repo operations jumps to $15 \%$ when the risk premium of the country concerned rises above 450 basis points. The reasoning used to justify this ruling is that a high risk premium indicates a high probability of default. This shows that for financial markets the issue is not the level of interest rates and their mechanical implications for debt sustainability. As Bund rates fall towards $1.5 \%$, a risk premium of 450 basis points

6 This is not needed for state governments in the US which do not have sizeable debt levels (on average less than $6 \%$ of GDP). 
implies a yield on Italian government bonds of about $6 \%$, hardly a level at which Italy's debt would no longer be sustainable, at least if one uses the 1990s as the benchmark. However, should the risk premium reach this level, a mechanical application of this rule would severely restrict the access of Italian banks to the interbank repo market.

Another, and perhaps even more important, liquidity squeeze results from the informal 'red lining' of all Italian (and in general peripheral) exposures by risk managers and supervisory authorities elsewhere in the EU and beyond: for instance, Denmark's biggest pension fund has ruled out accepting Italian (or even French) bonds as collateral. ${ }^{7}$ The perception of a pervasive 'counterparty risk' was also the main reason why the interbank market froze after the bankruptcy of Lehman. Unfortunately it seems that some regulators reinforce this effect by limiting even transfers within international banking groups (e.g. from the German subsidiary to the Italian headquarter bank). Until recently sovereign risk was not recognised at all within the eurozone. It seems now that some supervisors (mostly in the creditor countries) are making the crisis worse by going to the opposite extreme: all exposure to a country whose public debt trades at a risk premium is suddenly considered risky.

\section{Concluding considerations}

The idea that, within a monetary union, high levels of public debt lead inherently to more instability because higher interest rates on public debt could, in the end, make it more attractive to default than to increase taxes is intellectually appealing. But is it the best way to understand the euro crisis?

At the conceptual level, one important aspect overlooked by the literature is uncertainty. The models underlying the view that high public debt is inherently unstable in a monetary union usually assume a binary decision rule for the government: if interest rates are too high, it defaults; if interest rates are low enough, it does not. Thus there is no uncertainty once a threshold interest rate has been passed. However, in reality this is not the case. Even once the interest rate threshold has been set, much uncertainty persists as to whether there will be default or not.

One key reason for this uncertainty is that the future contains many sub-periods during which many important changes can take place. One particularly important factor is the political process. In reality, at least one and possibly several elections are likely to be held between the period in which interest rates are set in the market and the final period when the government decides whether to default and what haircut to impose on creditors. Different parties will compete and might have different views on default (or inflation). Some of them might oppose default on non-economic grounds, or because they have a different view of the cost of defaulting (inflation). There is thus a large range of interest rates over which there is some likelihood of a default (or inflation) and a lower range over which multiple equilibria might exist. Consistent with this idea Adrian \& Gros (1999) also find: "An increase in the uncertainty of the shocks hitting the economy reduces the parameter range in which multiple equilibria can arise."

However, these considerations reinforce the view that the fundamental problem behind the current eurozone crisis is liquidity both for banks and sovereigns. Two policy conclusions emerge:

- First, policy-makers in the creditor countries should realise that they might be condemned to continuously pump more funds into banking rescues and the European Financial Stability Facility (EFSF) until the moment when the supervisors impose a 'sudden stop' on the euro periphery, thereby depriving the banks and sovereigns of the periphery of liquidity.

- $\quad$ Second, the ECB should concentrate more on 'non-standard' measures to support the interbank market and to provide liquidity for the banking system, rather than keeping the yield on Italian government bonds low. Liquidity backstops for sovereigns should be reserved for extreme situations.

7 Other anecdotal evidence reported by Bloomberg. 


\section{References}

Adrian, T. and D. Gros (1999), "A stochastic model of self-fulfilling crises in fixed exchange rate systems", International Journal of Finance \& Economics, Vol. 4, No. 2, pp. 129-146.

Calvo, G. (1988) "Servicing the Public Debt: The Role of Expectations" American Economic Review, Vol. 78, No. 4, September, pp. 647661.

CBPP (Center on Budget and Policy Priorities) (2009), "How Legislation Enacted Since 2001 Contributed to Deficits Over 20012008", Washington, D.C.

De Grauwe, P. (2011) “Governance of a Fragile Eurozone", CEPS Working Document No. 346, CEPS, Brussels, May (http://www.ceps.eu/book/ governance-fragile-eurozone).

Diamond D.W. and P.H. Dybvig (1983), "Bank runs, deposit insurance, and liquidity", Journal of Political Economy, Vol. 91, No. 3, pp. 401-419.

Eichengreen, B., A.K. Rose and C. Wyplosz (1995), “Exchange Market Mayhem: The Antecedents and Aftermath of Speculative Attacks", Economic Policy, 21, pp. 249-312.
Giavazzi F. and M. Pagano (1996) "NonKeynesian Effects of Fiscal Policy Changes: International Evidence and the Swedish Experience", NBER Working Paper 5332, National Bureau of Economic Research, Cambridge, MA.

Gros, D. and T. Mayer (2011), "Refinancing the EFSF via the ECB", CEPS Commentary, CEPS, Brussels, August (http://www.ceps.eu/content/refinancing -efsf-ecb).

Kopf, C. (2011) "Restoring financial stability in the euro area", CEPS Policy Brief, CEPS, Brussels, March (http://www.ceps.eu/ book/restoring-financial-stability-euroarea).

Obstfeld, M. (1986), “Rational and Self-fulfilling Balance of Payments Crises", American Economic Review, 76, pp. 72-81.

Obstfeld, M. (1995), "Models of Currency Crises with Self-Fulfilling features", NBER Working Paper No. 5285, National Bureau of Economic Research, Cambridge, MA, October.

Sachs, J., A. Tornell and A. Velasco (1995), “The collapse of the Mexican Peso: What have we learned?", NBER Working Paper No. 5142, National Bureau of Economic Research, Cambridge, MA, June. 


\section{ABOUT CEPS}

Founded in Brussels in 1983, the Centre for European Policy Studies (CEPS) is widely recognised as the most experienced and authoritative think tank operating in the European Union today. CEPS acts as a leading forum for debate on EU affairs, distinguished by its strong in-house research capacity, complemented by an extensive network of partner institutes throughout the world.

\section{Goals}

- Carry out state-of-the-art policy research leading to innovative solutions to the challenges facing Europe today,

- Maintain the highest standards of academic excellence and unqualified independence

- Act as a forum for discussion among all stakeholders in the European policy process, and

- Providea regular flow of authoritative publications offering policy analysis and recommendations,

\section{Assets}

- Multidisciplinary, multinational \& multicultural research team of knowledgeable analysts,

- Participation in several research networks, comprising other highly reputable research institutes from throughout Europe, to complement and consolidate CEPS' research expertise and to extend its outreach,

- An extensive membership base of some 132 Corporate M embers and 118 Institutional Members, which provide expertise and practical experience and act as a sounding board for the feasi bility of CEPS policy proposals.

\section{Programme Structure}

\section{In-house Research Programmes}

\section{Economic and Social Welfare Policies}

Financial Institutions and Markets

Energy and Climate Change

EU Foreign, Security and Neighbourhood Policy

Justice and Home Affairs

Politics and Institutions

Regulatory Affairs

Agricultural and Rural Policy

\section{Independent Research Institutes managed by CEPS}

European Capital Markets Institute (ECMI)

European Credit Research Institute (ECRI)

\section{Research N etworks organised by CEPS}

European Climate Platform (ECP)

European N etwork for Better Regulation (ENBR)

European N etwork of Economic Policy

Research Institutes (ENEPRI)

European Policy Institutes N etwork (EPIN) 